\title{
INDETERMINATE CONTROL OF OFFENDERS: ARBITRARY AND DISCRIMINATORY
}

\author{
John Forbes Prrkins*
}

The American Law Institute bases its recommendation of the Youth Correction Authority Act on the following three general principles which were adopted by American Law Institute Advisory Committee on Criminal Justice-Youth, February 12, 1938. They read as follows:

(I) The objective of criminal justice should be the protection of society.

(2) The treatment of a condemned youth should take into account his characteristics and other causal factors of his conduct and should not depend on the crime of which he is guilty.

(3) The treatment should be directed primarily to the correction of his anti-social tendencies and he should be kept under control until it is reasonably certain that he is cured of these tendencies.

The thesis the Institute advances is that punishment has proved ineffectual as a deterrent of crime, and also as a corrective treatment of the criminal. Therefore it should be discarded. Instead of punishment each criminal shall receive the treatment best calculated to make him a good citizen, and as each person is different the particular treatment needed can be determined only after a study of each criminal. If it is apparent that no particular treatment is required, that the crime is merely an isolated incident which is unlikely to occur again, the criminal shall be discharged at once. If only a minor remedy seems indicated, he shall be given that remedy and if it appears to be successful he shall be discharged. If the disorder which caused him to commit the crime is more deep-seated, a prolonged course of treatment shall be applied. If and as soon as the treatment appears to be effective, the criminal shall be discharged. But should it prove ineffective, he shall be kept under control. In this way the objective of criminal justice which should be the protection of society will be attained as fully as possible.

\section{Thesis Based on a False Analogy to Cilinical Medicine}

This is an appealing thesis. It describes methods which correspond very closely to the methods of clinical medicine with which we are familiar. We know these are sound in dealing with sick people and, as crime may be regarded as a form of social

* A.B., 1899, LL.B., ז903, Fiarvard University. Member of the Massachusetts Bar. Judge of the Boston Jurcnile Court since 1932. Chairman, Board of Trustces, Massachusetts Training; Schools; member, War Labor Board, 1917-1918. 
illness, why should we not use a similar procedure in dealing with criminals? The proponents of the Youth Correction Authority Act constantly use the analogy of clinical medicine as support for their thesis.

But it is a true analogy? Reasoning by analogy is dangerous; for if the two situations are not really alike, but merely similar in certain respects, we may be led to overlook vital factors which should be taken into account and draw unwarranted conclusions. And these may lead to a plan which will aggravate rather than remove the evils which distress us. Therefore before assuming that the methods used successfully in clinical medicine will be successful in dealing with problems of behavior, let us compare the two situations and see if they are the same. At once two fundamental differences appear.

I. The doctor acts at the urgent request of the patient. The criminal has treatment forced upon him against his will. He does not put himself into the hands of the Authority and accept what it proposes to do. Like all people who have done something wrong and had attention called to it, he is humiliated and defensive. He has not surrendered his independence voluntarily. It has been forcibly taken away from him, and he is ready to seize upon the least sign of injustice as a basis for resentment.

2. The doctor adjusts conditions to suit the patient. He relieves him of responsibility and strain and as a rule the treatment calls for little or no effort by the patient. The criminal has to adjust himself to conditions, and his rehabilitation depends on his making an effort, for only by self-discipline can he overcome his weakness and gain the strength and self-control to meet the conditions which society imposes on its members. The treatment of a criminal calls for an extra step which does not exist in the treatment of a patient. Generally speaking, the doctor can decide what should be done and do it himself. The Authority after deciding what should be done, must secure the criminal's acceptance and get him to do it. If he refuses, nothing is accomplished. The criminal has the final decision. "One man can take a horse to water, but twelve men can't make him drink."

So the fact that the patient willingly accepts the doctor's decision is no assurance that a criminal will accept the Authority's decision, nor does the fact that a patient is indifferent to the treatment a doctor gives other patients mean that a criminal will be indifferent to the treatment other criminals receive. The analogy is false. The situations are not the same, and the fact that certain methods have been successful in clinical medicine is no warrant for believing that they will be successful in dealing with problems of behavior.

\section{Specific Examples of How the Proposed Act Would Work}

Concrete applications of a theory often enable us to test it better than we can by abstract argument. So let us take some concrete examples of how the Youth Correction Authority Act would work.

r. Four youths, $A, B, C$ and $D$, are committed to the Authority after being convicted of breaking into fur stores and stealing large amounts of furs. So far as their 
personal conduct and previous records are concerned there is nothing to justify distinction between them. Only in their personal characteristics does difference appear. But here it is markcd and, as a result of a study of their personal characteristics, $A$ is discharged, $B$ put on probation, $C$ is sent to the Reformatory, and $D$ to State's Prison. Is it not probable that all but $A$ will feel that they have been unfairly treated, that, unless the Authority can give objective proof why the discrimination should be made, they will feel their treatment unjust and resent it?

2. Two other youths, $E$ and $F$, are committed to the Authority. $E$ has been a sneak thief who has made a practice of getting into houses while the family was at dinner, and stealing jewelry from the bedrooms. His thefts amount to several thousand dollars. The experts who study him find that he is full of criminal ideation and he has a sense of regret, not for his stealing, but only for the mistake he made which led to his detection. Only a long course of training will change his attitude, they decide, and so he is sent to the Reformatory.

$F$ has stolen $\$ 200,000$ from his uncle, a leading banker. $F$ belongs to a prominent family and has acted as his uncle's private secretary. As the result of an affair with a girl who acted as decoy for a blackmailer, he finds himself under threat of exposure, and, terrified at the thought of the publicity and disgrace this would bring to his family, he tries to buy off the blackmailer. To do this he takes some of his uncle's bonds-having access to the latter's safe deposit box-and in the hope of recouping, takes some more bonds, speculates in the market and loses. This process goes on until his uncle discovers what has happened. At the trial the whole story is brought out and the newspapers play it up in the headlines.

The experts study the boy, find that the cause of his actions was fear of exposure and, now that the worst has happened and there is nothing left to run away from, it is extremely unlikely that he will do anything criminal again. $\mathrm{He}$ is a marked man; it is improbable that he will be again given a position of financial trust which would enable him to commit a similar offense. Personally he has excellent qualities, he is free from criminal tendencies and after the tremendous experience he has been through, his sole and controlling desire is to redeem himself. Under Section 29 (2) the Authority feels compelled to order his immediate discharge. This reads as follows:

Section 29 (2) The Authority shall discharge such person as soon as in its opinion there is reasonable probability that he can be given full liberty without danger to the public.

What will be the feelings of $E$ who has stolen a few thousand dollars of jewelry at seeing $F$ go free? $E$ 's offense involved risk and skill, and violated no personal confidence. $F$ on the other hand stole $\$ 200,000$ and took advantage of his uncle's trust.

Is the discharge of $F$ a good example for the public?

Examples $I$ and 2 raise questions regarding discrimination based on personal characteristics. The examples which follow raise different questions. 
3. $G$ has been guilty of stealing a number of automobiles. At the time of commitment he is a harum-scarum boy and the Authority thinks he requires an extended period of training. He enters on it cheerfully. But after a time he gets tired of the discipline and asks for discharge. He has seen other boys who came to the Authority after him get through and go free, feels that he has done as well as they have, that his offense was less serious than theirs, and believes he ought to be let go. The experts try to make him see that he has characteristics which require a longer period of training. This he won't admit. He says they are showing favoritism and have it in for him. He becomes resentful, morose and antagonistic; and when at the end of two years he is again studied he is found to be intensely anti-social, full of criminal ideation, and only wants a chance to get even with society. $\mathrm{He}$ is transferred to State's Prison, marked as a dangerous man, and at the age of twenty-five the Authority applies to the Court for the extension of its control over him for another period of five years. This is granted. $G$ becomes progressively more bitter and antagonistic; at the end of each five-year period the Authority's control is extended for another five years, until he dies at the age of seventy, having spent all his mature life in prison.

4. $H$ is an embezzler. After a course of training by the Authority he is tested in a number of occupations which provide opportunities to steal and proves himself trustworthy. But the experts who study him come to the conclusion that he is a potential rapist and a dangerous person to be at large. So, although $H$ has overcome the weakness which led to his crime, the Authority decides in accordance with Section 29 (I) that, for the protection of the public, it is necessary to keep him under its control, and, as neither the Authority nor the Court is willing to discharge him, he remains in State's Prison until he is an old man.

\section{Questions Ratsed by the Examples}

These examples raise certain questions, some of which have been indicated.

I. Is it possible to secure experts in each state who are capable of determining accurately what the personal characteristics of each criminal are, and just what his treatment should be?

2. Assuming that there are sufficient experts to do this, will they also be capable of inducing each criminal to accept the treatment indicated?

3. Will a criminal be indifferent to the treatment other criminals receive or will he compare his treatment with that of others and resent their "getting a better break" than he does?

4. If he does not accept the treatment prescribed, how successful is it likely to be?

5. Shall control of the criminal be retained indefinitely because the Authority is not successful in securing his cooperation?

6. Shall control of the criminal be retained after he has overcome the fault which led to his crime, because the Authority discovers another personal characteristic which it considers dangerous? This characteristic has never expressed itself in crime. The criminal has never been tried and convicted for it, and yet the Authority believes 
it makes him a dangerous person to be at large. Does Section 29(I) require that he be kept under control? It reads as follows:

The Authority shall keep under continued study a person in its control and shall retain him subject to the limitations of $\$ \$ 28(4)$ and 32 under supervision and control so long as in its judgment such control is necessary for the protection of the public.

Some of the difficulties raised by the examples given and the questions they suggest perhaps might be cured by re-wording the language of the Act, but others indicate fundamental difficulties.

\section{The Main Difficulty: Arbitrary Discrimination}

The main difficulty is this: The American Law Institute proposes to discriminate between criminals without regard to what they have done, to base the discrimination on their personal characteristics not as shown by any objective demonstration, but as determined by a study made by the Authority with no representative of the criminal present. On its conclusions from this study without regard to any specific conduct by the criminal, and without regard to what happens to any other criminal, the Authority imposes a course of disciplinary training. The American Law Institute proposes to measure the restrictions imposed on human liberty by what the Authority thinks of the personal qualities of the criminal, not by the criminal's conduct.

Is not this what we mean by arbitrary discrimination, in short, injustice?

Is it not the use of arbitrary power, and as Roscoe Pound has said: "If there is anything which has been demonstrated in legal history it is the deep-seated human repugnance to subjecting any person to the arbitrary will of another." The power is no less arbitrary because its exercise is subject to judicial review, since no definite, objective standards are provided for the reviewing court to apply.

Is it not contrary to what we have always meant by equality under the law?

Does it not reverse the principle of a government of laws and not of men? Is not the American Law Institute proposing a government of men and not of laws?

When I have raised these objections to proponents of the Act they have calmly assured me that these objections are based on the old punitive idea, and that the criminals would accept the treatment recommended by the Authority because it is correctional treatment, not punishment.

This is mere assertion. We are dealing with habits and attitudes built up from childhood that have become ingrained, and these are not likely to be changed by calling an undesired discipline by a pleasant name. The parent's assurance to the child he is punishing-"I am doing this for your good, Henry"-has never been convincing to the child.

\section{Fair Play a Fundamental Demand}

Consider briefly how we deal with our children. In early childhood we seek to encourage desirable tendencies and discourage primitive tendencies. We approve and applaud a child's sharing things with his brothers and sisters; we disapprove and 
diścourage his grabbing things from them and using force and violence to get what he wants. The tools we have to work with are rewards and punishments, pleasure and pain, inspiration and discipline which are simply different names for the means we use to make our approval or disapproval effective. In the early years these take rather crude forms as we build up conditioned reflexes, but as children grow older they may take an infinite number of forms. The underlying idea, however, is that reward is a desired result for doing right, and punishment an undesired result for doing wrong. If the parent-child relationship develops happily, the mere approval or disapproval of the parent means reward or punishment. We have all heard a child say, "Oh Mummy, please don't be cross at me." The mother's disapproval is painful, and the pain destroys the satisfaction which the child had received from gratifying its primitive impulse. If the parent-child relationship does not develop happily, cruder forms of approval and disapproval have to be used to stimulate right action and to check the primitive impulses.

Throughout this process-which I have merely sketched-the measure by which approval is determined is not a child's personal characteristics but how well or how badly he has done what he was supposed to do. The parents study his characteristics and arrange tasks which are calculated to correct the bad tendencies and to encourage the good, but he is measured by the way he performs the task, not by his characteristics, and he receives praise or blame for what he does, not for his personal qualities. His life is a series of successes and failures, and the measure is always what he has done. The same is true in his school, in his music lessons, his games. His arithmetic is right or wrong, he strikes the right note on the piano or the wrong one, he pitches a ball or a strike. He sees the same measurement used on all the other children around him, and jealously watches to see that other children are not being favored. And as one of the difficulties he has to overcome is the bullying of other boys he learns to stand on his own feet and to make others prove their right to do something he does not like. He wants his fair share and so do-his playmates, and unless there is concrete evidence to show why one should be preferred to the other, even shares are the only satisfactory division. The demand for equality under the law is not a political slogan nor a metaphysical concept conceived by a philosopher. It is simply the result of what children have found from infinite experience since the beginning of time to be the essential element of living together successfully. It is what we mean by fair play.

\section{Liberty Also a Fundamental Demand}

The same thing is true about our demand for liberty. It is no catch phrase. We don't willingly accept discipline. We are jealous of our independence. If we consider our various relationships, we realize that the doctor is almost the only person in whose hands we place ourselves unreservedly, and whose decisions we unhesitatingly accept. Children make no such surrender to their parents, although to them their parents are all-powerful. Unless the restrictions imposed on them seem reasonable and just, they are likely to rebel. Day after day in the Juvenile Court I find myself 
dealing with "stubborn children" who have been made so because their parents have been arbitrary and unfair. Children make no such surrender to their schoolteachers. In school they recognize the right of a teacher to give orders, but if he tries to correct them out of school hours he is likely to receive a "Bronx cheer." Employees accept the employer's right to impose conditions which are necessary for the satisfactory accomplishment of the work, but if he imposes unnecessary restrictions for which there is no apparent reason they object; and if he attempts to direct their lives outside of working hours, trouble inevitably results, as many paternalistic employers have found to their cost. The person who interferes with our independence must affirmatively prove why he should interfere or we resent it. We all know how we feel about a back-seat driver.

The demand for liberty, like the demand for equality, is age-old. Both spring from the same source, man's insistence that he be judged by his deeds.

\section{Social Protection Subordinated to Liberty}

This raises a question about the protection of the community which the American Law Institute so strongly emphasizes. "The objective of criminal justice should be the protection of society" is the first and underlying principle on which it bases its thesis.

In this principle true? Or is it true that "the objective of criminal justice should be the degree of protection which is best calculated to produce a vigorous, self-reliant and orderly people," which is a very different thing. Protection is not an end in itself. It is simply a means to an end, merely one of the factors which contribute to the welfare of society. We may need more or less of it from time to time as conditions change; but in this country we have always regarded it of subordinate importance, merely as the handmaiden of liberty.

Throughout this country and the whole British Commonwealth we have a rule that no man shall be convicted of a crime unless he is proved to have committed it, not merely by a preponderance of evidence, but beyond a reasonable doubt. In the greater part of this area, the proof must be unanimously agreed to by all twelve jurors. Elaborate rules of evidence have been devised to prevent prejudice, preconceptions, or any other element which does not have direct probative value regarding the offense from entering into the decision. In other words we shall not be deprived of our liberty unless it can be unquestionably established that we have done something wrong.

How relatively little we value protection and how greatly we value liberty is shown by the way well-known racketeers and gangsters are allowed to move about freely. It is a disgraceful situation. Who they are and what they have done is notorious, but, for fear of impairing our liberty, we have imposed restrictions on our power to deal with them, and, in the absence of ciear proof of a specific crime, they go unmolested. But as compensation for the deplorably large number of criminals who are never convicted, we have a sense of thankfulness when we see what is going 
on abroad, where the fact that a man is a Jew is enough to put him in prison, where no proof of wrong-doing is required, and the opinion of the official controls. We are proud that before the law all men are equal, that race or religion, or position, high or low, makes no difference. A man is accountable only for what he has done.

The American Law Institute proposes to change all this. Protection is to take the place of liberty and equality. No longer will a man be accountable merely for what he has done. What happens to him will depend on what a public official thinks of him.

\section{The Fallacy of the Institute's Position}

It seems pretty clear that the American Law Institute has got off the road. What is the explanation? Is it not this: that the Institute has made the common mistake of identifying an instrument with its misuse. And having done this it has fallen into the further error of thinking it can change a fundamental human attitude by calling an undesired discipline by a pleasant name.

The Institute takes the position that punishment has an inherent quality of its own, that it is hurting a person for the sake of hurting him, and that corrective treatment is essentially different. Probably it would admit that a law enforcement system based on punishment must be built on the principles of liberty and equality, and that in such a system arbitrary discrimination would be unacceptable. But the Institute maintains it is proposing an entirely different system-something which is new. ${ }^{1}$ It insists the existing system is bad because it has always been punitive. The system proposed by the Institute will be good because it is corrective. It will substitute corrective treatment for punishment. Punishment entirely disappears and corrective treatment takes its place; and as this is designed to help not hurt the criminal, questions regarding liberty and equality and discrimination do not arise. .

Unfortunately for the Institute's contention this argument does not avoid the difficulty. For the Authority calls its treatment compulsory education; and arbitrary discrimination is just as unacceptable in school or any other compulsory discipline as is it in punishment. Much of my time is given to talking to boys who hate school. They should not be made to go to school for they cannot learn, but if they are excused many other boys in the neighborhood refuse to go. "If Freddy does not have to go to school," they say, "I don't see why I should have to." And they play hooky. So I have to try to make the inadequate boys see that going to school is just one of the

${ }^{1}$ In Waite, Twenty-seven Questions and Their Answers about the Plan for a Youth Correction Authority (A. L. I., mimeo.), it is stated, at p. 9: "'Punishment' and 'rehabilitation' are inherently inconsistent. The former depends for its effectiveness upon fear created by means of suffering. Rehabilitation, on the other hand, may require that fear be allayed. Usually it will call for treatment that is no more punishment than every type of education, of training in trade skills, of correction of vision or removal of a defective tooth is punishment. Indeed in a sense, compulsory education in ability to carn a law-abiding living is reward not penalty; ...."

In the Introductory Explanation, Youth Correcrion Aurhority Act (A. L. I., Official Draft, 1940), it is stated, at p. xi: "Nevertheless, despite these beginnings, by thoughtful administrators of the penal system, the essential fault remains. The system was conceived for the purpose of punishment, not for reform. Even when it now talks reform, it still uses the language of punishment. It is still a penal system and not a process designed for rehabilitation." 
disagreeable jobs of life which they have to put through, and that it is good training in "learning to take it." If a boy is excused, the only thing the boys who are not excused can see is that another boy is getting a special privilege which is denied them and no amount of explaining about Freddy's peculiarities and limitations carries any conviction.

Still more unfortunately in trying to sustain its argument the American Law Institute has made statements about the history of our penal institutions which are not only misleading but are plain mistatements of fact. A comparison of the statements of the Institute with statements made a hundred years ago as shown below ${ }^{2}$ establish this beyond question. Corrective treatment is not substantially a new idea nor have we relied on "punishment" and "punishment alone" as the Institute contends. A single quotation from a report made one hundred and three years ago shows this quite clearly:

The third point referred to is one we would particularly ask attention to; it is the need to have a House of Refuge to which all boys and girls violating the law may be sent, there to be educated, reformed and made worthy of society and saved from a life of sin.

The first institutions of this kind were founded in Germany by individuals about $18 \mathrm{r}_{3}$, I825, one was formed in New York by a society; Boston founded one in $x 826$ and Philadelphia in $1828 .^{3}$

These Houses of Refuge were forerunners of our Industrial Schools which are now all over the country. If it is possible to make a statement less "punitive" in character than the purpose of these Houses of Refuge- "there to be educated, reformed, and made worthy of society and saved from a life of sin"-it is hard to conceive what it would be. And so far as boys were concerned these institutions included the age group for which the Youth Correction Authority Act is designed.

\footnotetext{
${ }^{2}$ Cf. Introductory Explanation, Yourh Correction Aurhority Acr (A. L. I., Official Draft, 1940) ix: "Traditionally the criminal law has relied upon punishment and the threat of punishment as the only method of building up resistance to criminal inclinations."

In the N. Y. PRIson Ass'N RePORT FOR 1846, Samucl Gridley Howe wrote, at pp. 21-22: "The doctrine of retributive justice is rapidly passing away and with it will pass away, I hope, every kind of punishment that has not the reformation of the criminal in view."

Cf. Introductory Explanation, stupra, at p. xiv: "The Act as a whole is novel, however, because it frankly and specifically departs from the merely punitive ideas of dealing with criminals and sets up the objective of rehabilitation. It is designed to protect the public from repeated crime; first by safe segregation of dangerous persons so long as segregation is necessary; second by such treatment of individual wrong-doers as is calculated to increase the probability that they will refrain from crime thereafter."

Cf. Report for Public Meetings in Cincinnati on Prison Reform 1838-1839, quoted from J. H. Penkins, Memolr and Writings (1851): "In Pennsylvania, as we have said, reform began in 1786 and the penitentiary system was commenced by the establishment of the Walnut Street Prison. The idea in founding this prison seems to have been this, - to protect society by confining the criminal and to reform as far as possible the criminal himself so that he might not be criminal again as soon as free. The idea we think a noble and true one, uniting policy and benevolence; but the execution of it was most faulty, cte."

Cf. Waite, Truenty-seven Questions and Answers, supra note 2, at p. 29: "That incarceration plus rehabilitative treatment must be far more effective than incarceration alone is so logically evident as to lcave no question of its desirability."

Cf. Report for Public Meetings in Cincinnati on Prison Reform, $1838-1839$, supra: "We turn to the inquiry. What species of labor shall the convict be employed on? Keeping in mind that one great end is to prevent a convict from becoming criminal again when free, we answer, that it must be if possible a species of labor that will support him when he leaves prison, etc."
}

${ }^{8}$ Report for Public Meetings in Cincinnati on Prison Reform 1838-1839, supra note 2. (Italics added.) 
Furthermore, the Institute contradicts its own contention that punishment and rehabilitation are inherently inconsistent by saying that punishment may be necessary for therapeutic purposes. In other words, its quality is not inherent, but depends on who uses it. In short, it is an instrument. This is confirmed by the proposal to place youths in existing institutions for correctional treatment. The Institute suggests no change in the management of the institutions and says their character is punitive; but if youths are placed in them by the Authority it maintains that the effect will be correctional. One can imagine the following conversation at the Concord Reformatory between Tom, age twenty-four, who has been committed by a court, and Henry, age twenty, who has been placed there by the Authority. They are hoeing beets in the vegetable garden. "Tom," says Henry, "what are you here for?" "Oh," says Tom, "I am here for retributive punishment. What are you here for?" "Oh," says Henry, "I am here for correctional treatment." And they resume their hoeing.

\section{Correction and Prevention, the True Purposes of Punishment}

As said before, I believe the true purpose of punishment is correction, but it is an instrument, and like any instrument, can be used wisely or stupidly, for the purpose for which it was designed, or for some improper purpose. It has no inherent quality of its own. The effect it produces depends on the user. Punishment is punishment because it is an undesired discipline imposed for wrong-doing, not because of the nature of the discipline. It is a frequent experience for me to have a mother come into court and say-"Judge, please can't Tony be taken off probation? I think he has been punished enough."

"Punished," I reply, "What do you mean? We have had extra milk put in your house, we've had Tony's teeth fixed. We got him into a club and arranged for him to go to camp for the summer. The only thing he's had to do is to report and do what you should have made him do anyway."

"I know Judge, but please can't you let Tony off probation? I think he has been punished enough."

In support of this conception of punishment, let me quote the following passage:

Who is so foolish as to chastise or instruct the ugly or the diminutive or the feeble? And why not? Because he knows that good and evil of this kind is the work of nature and of chance; whereas if a man is wanting in the good qualities which are attained by study and exercise and teaching and has only the contrary evil qualities, other men are angry with him and punish and reprove him.... In such cases any man will be angry with another and reprimand him-clearly because he thinks that by study and learning, the virtue in which the other is deficient may be acquired. If you will think of the nature of punishment you will see at once that in the opinion of mankind virtue may be acquired; no one punishes the evil doer under the notion or for the reason that he has done wrongonly the unreasonable fury of a beast acts in that manner. But he who desires to inflict rational punishment does not retaliate for a past wrong which cannot be undone; he has regard for the future and is desirous that the man who is punished and he who sees him punished may be deterred from doing wrong again. He punishes for the sake of prevention, thereby clearly implying that virtue is capable of being taught. ${ }^{4}$

‘Plato, Dialogues (Jowett's trans., 3d ed. 1892) "Protagoras," 323-324. 


\section{The Futility of Merely Changing a Name}

Let us stop thinking we can change something by calling it by a different name. It is a silly business. We can't avoid the unpleasant realities of life by saying they are not there. In the field of penology we have been peculiarly subject to this illusion. Appalled by the conditions in prisons, we built penitentiaries, houses of correction, reformatories, but the name has identified itself with the character of the institution. The institution has not taken on the quality of the name. Let us learn a lesson from the doctors. A hundred years ago, hospitals were regarded with horror and dread, particularly by the poor. They were houses of death. Now each morning long lines of people crowd into the Out-Patient Clinics. Hospitals are no longer houses of death. They are houses of life, for they save life, relieve pain and bring comfort and hope to countless thousands of people. But they are still called Hospitals.

The American Law Institute has done a valuable service in calling attention to the folly of a ritualistic attitude which demands prison as a prescribed and inevitable sequence to conviction. If an embezzler is in a work camp in the mountains the community should be as well protected against his particular form of misdeed as if he were in prison. If we can devise properly supervised disciplines which leave the criminal in the community without danger to the community there is no sense in locking him up in prison. Prison is artificial. In spite of much devoted and intelligent effort experience has shown that it is intensely difficult to make a prison a constructive correctional instrument. But the difficulty arises from the nature of mankind and our limited power to influence the behavior of others, and was not created by our adopting a "punitive" rather than a "rehabilitative" attitude. Let us face the problem squarely with the searching scientific spirit the doctors have shown. If we do that and are persistent and devoted we shall make progress. But we shall never get anywhere if we think that by the adroit use of language we can safely disregard the fundamental human longing for fair play. 